\title{
PENGARUH RELATIONSHIP MARKETING TERHADAP CUSTOMER RETENTION ORIENTATION NASABAH BANK SYARIAH DI KOTA \\ MALANG
}

\author{
Oleh: \\ Irmayanti Hasan*)
}

\begin{abstract}
Abstrak
The increasing stringency emulation at banking industry, especially the islamic banking industry, brings the importance of relationship improvement between islamic banks with their costumers. By using relationship marketing as one of the key action to reach costumers' retention orientation, this research aims to analyze the direct influences, both simultaneously and partially, of variables: belonging, communication, customization, differentiation, personalisation and security, and convinience to costumers' retention orientation of islamic banks in Malang.

The samples are taken from two islamic bank branches in Malang, those are: PT. BRI SYARIAH MALANG BRANCH and PT. BTN SYARIAH MALANG BRANCH. This research applies the quantitative approach, by means of the surveys to take samples from the population, and questionaires to collect the principal data. Number of samples is determined by Slovin's formula with proportional sampling method to each population: 65 customers of PT. BRI SYARIAH MALANG BRANCH and 35 customers of PT. BTN SYARIAH MALANG BRANCH. Multiple regression analysis is used to predict the relationship between variables.

Hypothetic test using $F$ test indicates that the significant simultaneous influence of relationship marketing variables; those are belonging (X1), communication (X2), customization (X3), differentiation (X4), personalization (X5), and security and convenience (X6) to customers' retention orientation $(Y)$ is acceptable. The test partially indicates that the significant influence of belonging (X1), communication (X2), and customization (X3) to customers' retention orientation $(Y)$ is acceptable, while the significant influence of differentiation (X4), personalization (X5), and security and convenience (X6) is unacceptable.
\end{abstract}

Key words : Relationship Marketing dan Customer Retention Orientation

\section{PENDAHULUAN}

\section{Latar Belakang}

Dalam beberapa puluh tahun terakhir, konsep pemasaran (marketing) sudah berkembang dengan sangat cepat. Sejak mass marketing muncul pada tahun 1950-an dengan strategi produksi massal untuk menekan biaya produksi seminimal mungkin, kemudian target market pada tahun 1980-an, dan customize marketing pada tahun 1990-an sampai era globalisasi tahun 2000-an ini, konsep 
pemasaran telah berkembang menjadi one to one marketing dengan salah satu strategi yang populer saat ini customer relationship marketing. (Freddy Rangkuti, 2006;ix).

Kepuasan pelanggan bukanlah konsep baru, di awal abad 20 sudah banyak perusahaan yang memahami bahwa kepuasan pelanggan adalah hal yang sangat penting. Sampai hari ini, kepuasan pelanggan masih merupakan konsep yang sangat relevan. Logika sederhana dari pelaku bisnis adalah bahwa pelanggannya puas, pasti akan membuat dampak positif bagi kelangsungan hidup perusahaan.

Menurut Freddy Rangkuti (2006;3), kepuasan pelanggan berakibat pada loyalitas pelanggan, loyalitas merupakan gabungan antara proses intektual dan emosional, antara pelanggan dan perusahaan. Dengan adanya pelanggan yang loyal, perusahaan perlu mempertahankan pelanggan (customer retention orientation). Untuk mempertahankan pelanggan yang ada perusahaan dapat menggunakan strategi hubungan pemasaran (relationship marketing). Menurut Chan $(2003 ; 6)$, relationship marketing dapat didefinisikan sebagai "Pengenalan setiap pelanggan secara lebih dekat dengan menciptakan komunikasi dua arah dengan mengelola suatu hubungan yang saling menguntungkan antara pelanggan dan perusahaan". Sehingga dapat dikatakan bahwa relationship marketing menyediakan suatu pendekatan yang akan membantu perusahaan untuk menciptakan hubungan dengan pelanggan dan pihak lain yang berkaitan dalam proses bisnis, serta menganggap relationship marketing sebagai suatu strategi.

Dalam jurnal penelitian yang dilakukan oleh Odekerken-Schroder, de Wulf and Reynolds $(2000 ; 2)$ terdapat tujuh kategori upaya relationship marketing (relationship marketing efforts) yaitu belonging, communication, customization, differentiation, personalization, rewarding, dan security and convenience. Salah satu tujuan dari penggunaan program relationship marketing adalah fokus pada customer retention. Berry (dalam Kandampully and Duddy, 1999;13) menyatakan bahwa kesuksesan perusahaan tergantung pada kemampuannya untuk mempertahankan pelanggan (customer retention). Retensi pelanggan 
(mempertahankan pelanggan yang sudah ada) jauh lebih murah dibandingkan mencari pelanggan baru (Rangkuti, 2000;35).

Pergerakan tren baru ini (relationship marketing) dipelopori oleh Amerika Serikat. Fenomena yang sama juga terjadi di Indonesia. Satu per satu perusahaan di Indonesia mulai menerapkan relationship marketing. Di dunia perbankan, relationship marketing dipelopori oleh Bank Central Asia (BCA), bank Niaga, bank Mandiri, BII, Citibank, HSBC (Chan, 2003). Dalam Chan (2002), industri perbankan merupakan industri yang mengadopsi relationship marketing sebagai strategi pemasarannya untuk membangun hubungan (relationship building) dengan nasabah.

Berkembangan perbankan syariah yang semakin cepat dan pesat, semakin membuat persaingan ketat antara bank-bank syariah yang ada. Begitu juga berkembangan bank syariah di Jawa Timur. Untuk mengatasi persaingan yang semakin meningkat, maka perbankan syariah harus dapat meningkatkan kepuasan nasabah serta akhirnya dapat mempertahankan nasabah. Sehingga dalam hal ini perbankan syariah dirasa perlu mengikuti perkembangan strategi pemasaran yang telah berkembang pesat tersebut. Yaitu dengan menerapkan strategi relationship marketing dengan harapan dapat mempertahankan nasabahnya (customer retention orientation).

Untuk dapat membangun hubungan yang baik dengan para nasabahnya, perusahaan perbankan syariah dapat menggunakan relationship marketing sebagai salah satu kunci untuk mencapai customer retention orientation (Kotler, 2000;15), maka dilakukan penelitian dengan judul "Pengaruh Relationship Marketing Terhadap Customer Retention Orientation Nasabah Bank Syariah Di Kota Malang".

\section{Rumusan Masalah}

1. Apakah variabel relationship marketing yang terdiri dari belonging, communication, customization, differentiation, personalization dan security and convenience mempunyai pengaruh langsung secara simultan terhadap customer retention orientation pada nasabah bank syariah di Kota Malang? 
2. Apakah variabel relationship marketing yang terdiri dari belonging, communication, customization, differentiation, personalization dan security and convenience mempunyai pengaruh parsial terhadap customer retention orientation pada nasabah bank syariah di Kota Malang?

\section{Tujuan}

1. Untuk menganalisis pengaruh langsung secara simultan variabel relationship marketing yang terdiri dari belonging, communication, customization, differentiation, personalization dan security and convenience terhadap customer retention orientation pada nasabah bank syariah di Kota Malang.

2. Untuk menganalisis pengaruh langsung secara parsial variabel relationship marketing yang terdiri dari belonging, communication, customization, differentiation, personalization dan security and convenience terhadap customer retention orientation pada nasabah bank syariah di Kota Malang.

\section{KAJI AN PUSTAKA}

\section{Konsep Pemasaran}

Menurut Kotler (2001:23) konsep pemasaran adalah pencapaian tujuan organisasi tergantung pada penentuan kebutuhan dan keinginan pasar sasaran (target market). Pemasaran merupakan salah satu kegiatan-kegiatan pokok yang dilakukan oleh perusahaan untuk dapat mempertahankan kelangsungan hidupnya (survive), berkembang (growth), dan mendapatkan laba (profit). Pemasaran merupakan suatu interaksi yang berusaha untuk menciptakan hubungan pertukaran. Pemasaran dilakukan oleh individu dan organisasi dengan tujuan terciptanya pertukaran guna memenuhi dan memuaskan kebutuhan dan keinginan baik penjual maupun pembeli.

\section{Manajemen Pemasaran}

Menurut Kotler (2001:18) manajemen pemasaran (marketing management) adalah proses analisis, perencanaan, implementasi dan pengendalian programprogram yang dirancang untuk menciptakan, membangun dan memelihara 
pertukaran yang menguntungkan dengan pembeli sasaran untuk mencapai tujuan perusahaan.

Pemasaran termasuk salah satu kegiatan dalam perekonomian yang membantu dalam menciptakan nilai ekonomi dan nilai ekonomi ini akan menentukan harga barang dan jasa bagi individu. Bagi perusahaan, fungsi perusahaan adalah penting sebagai salah satu usaha untuk terus hidup, berkembang dan mendapatkan laba sesuai dengan tujuan yang telah ditetapkan sebelumnya.

Menurut Swasta dan Irawan (2000:15) menjelaskan unsur konsep pemasaran ada tiga yang terdiri dari konsep pemasaran harus berorientasi kepada konsumen, harus disusun secara integral dan yang ketiga adalah harus mengutamakan kepuasan konsumen. Masing-masing unsur tersebut dapat diuraikan sebagai berikut :

1. Orientasi Kepada Konsumen

2. Penyusunan Kegiatan Pemasaran Secara Integral

3. Kepuasan Konsumen

\section{Manajemen Pemasaran Jasa}

Menurut Kotler (2001:35) mendefinisikan jasa sebagai berikut: “Setiap tindakan atau unjuk kerja yang ditawarkan oleh salah satu pihak ke pihak lain yang secara prinsip intangible dan tidak menyebabkan perpindahan kepemilikan apapun. Produksinya bisa saja terikat dan bisa juga tidak terikat pada suatu produk fisik.". Zeithmal dan Bitner (dalamYazid, 2001:62) menyebutkan bahwa, “Mencakup semua aktivitas ekonomi yang outputnya bukanlah produk atau konstruksi fisik, yang secara umum konsumsi dan produksinya dilakukan pada waktu yang sama dan nilai tambah yang diberikannya dalam bentuk yang secara prinsip intangibel (kenyamanan, hiburan, kecepatan dan kesehatan) bagi pembeli pertamanya"

Menurut Tjiptono (2002:15) perusahaan jasa memiliki beberapa ciri utama yang sangat mempengaruhi program pemasarannya yaitu: 1). jasa itu tidak berwujud (intangibel), 2). tidak terpisahkan (inseparabel), 3).bervariasi (variability) dan 4). tidak tahan lama (perishability).

\section{Kepuasan pelanggan}


Menurut Rangkuti (2001;30), kepuasan pelanggan didefinisikan sebagai respons pelanggan terhadap ketidaksesuaian antara tingkat kepentingan sebelumnya dan kinerja aktual yang dirasakannya setelah pemakaian. Tjiptono (2002;161) ada beberapa strategi yang dapat dipadukan untuk meraih dan meningkatkan kepuasan pelanggan antara lain:

- Relationship Marketing,

- Strategi Superior Customer Service

- Strategi Unconditional Guarantees

- Garansi atau jaminan istimewa.

- Strategi Penanganan Keluhan yang Efektif

- Strategi Peningkatan Kinerja Perusahaan

- Quality Function Deployment

Pemasaran Transaksional dan Hubungan Pemasaran (Relationship Marketing)

Tabel 2.1.

Perbedaan Transactional Marketing dan Relationship Marketing

\begin{tabular}{|c|c|c|}
\hline Karakteristik & Transactional Marketing & Relationship Marketing \\
\hline Orientasi waktu & Pembelian dilakukan sekali & $\begin{array}{l}\text { Pembelian dilakukan berulang- } \\
\text { ulang }\end{array}$ \\
\hline $\begin{array}{l}\text { Hubungan } \\
\text { pelanggan }\end{array}$ & $\begin{array}{l}\text { Hubungan dengan pelanggan } \\
\text { sangat terbatas }\end{array}$ & $\begin{array}{l}\text { Hubungan dengan pelanggan } \\
\text { sangat dekat/sering }\end{array}$ \\
\hline Prioritas layanan pelanggan & Fokus pada keuntungan produk & $\begin{array}{l}\text { Fokus pada keuntungan nilai } \\
\text { pelanggan }\end{array}$ \\
\hline $\begin{array}{l}\text { Tingkat } \\
\text { pelanggan }\end{array}$ & $\begin{array}{l}\text { Perhatian pada pelanggan } \\
\text { untuk jangka waktu yang } \\
\text { pendek }\end{array}$ & $\begin{array}{l}\text { Perhatian pada pelanggan untuk } \\
\text { jangka waktu yang lama }\end{array}$ \\
\hline $\begin{array}{l}\text { Dasar hubungan penjual- } \\
\text { pelanggan }\end{array}$ & Pelayanan yang terbatas & $\begin{array}{l}\text { Pelayanan pada tingkat yang } \\
\text { tinggi }\end{array}$ \\
\hline Tujuan organisasi & Menciptakan penjualan & Mempertahankan pelanggan \\
\hline Sumber kualitas & $\begin{array}{lll}\text { Kualitas } & \text { tanggung } & \text { jawab } \\
\text { produksi } & & \end{array}$ & $\begin{array}{lll}\begin{array}{l}\text { Kualitas } \\
\text { organisasi }\end{array} & \text { tanggung } & \text { jawab }\end{array}$ \\
\hline
\end{tabular}

Sumber: Jenu Widjaja Tandjung $(2004 ; 90)$

Menurut Chan $(2003 ; 6)$, relationship marketing dapat didefinisikan sebagai "Pengenalan setiap pelanggan secara lebih dekat dengan menciptakan komunikasi dua arah dengan mengelola suatu hubungan yang saling menguntungkan antara pelanggan dan perusahaan".

\section{Tipe Strategi Hubungan (Relationship strategy)}

Menurut Rangkuti (2002;137) tipe huungan yang dapat dibentuk oleh suatu perusahaan dapat berupa: 
1. Hubungan vertikal (pemasok dan pembeli) yaitu:

a. Hubungan pelanggan - pemasok.

b. Distribusi channel relationship.

c. Hubungan end-user customer (hubungan strategis dengan pelanggan untuk meningkatkan kepuasan pelanggan dan mempertahankan pelanggan).

2. Hubungan horizontal.

3. Hubungan internal, yaitu terjadi di dalam bisnis unit, departemen fungsional dan pekerja individual.

\section{Hubungan Pemasaran dalam perspektif Islam}

Dalam sejarah Rosulullah SAW, kesuksesan dalam berbisnis dilandasi oleh dua hal pokok, yaitu: kepribadian yang amanah dan terpercaya serta pengetahuan dan ketrampilan yang mumpuni. Keduanya merupakan pesan moral yang bersifat universal yang bisa dikaitkan dengan sikap karyawan dalam melayani pelanggan sebagaimana uraian dibawah ini (Didin dan Hendra, 2003: 54):

1. Shiddiq, Yaitu benar dan jujur, tidak pernah berdusta dalam melakukan transaksi bisnis.

2. Kreatif, berani dan percaya diri, ketiga hal ini mencerminkan karyawan untuk berusaha mencari kebutuhan pelanggan sehingga keinginan pelanggan dapat dipenuhi oleh perusahaan dan bisa menyelesaikan keluhan pelanggan dengan cepat.

3. Tablig, yaitu mampu berkomunikasi dengan baik.

4. Istiqomah, Artinya konsisten dalam iman dan nilai-nilai yang baik meski menghadapi berbagai godaan dan tantangan.

5. Amanah, Berarti memiliki tanggungjawab dalam melaksanakan tugas dan kewajiban.

6. Fathonah, Berarti mengerti, memahami dan menghayati secara mendalam segala hal yang menjadi tugas dan kewajibannya.

\section{Model Hipotesis}

Model hipotesis pada penelitian ini adalah sebagai berikut:

1. Diduga variabel relationship marketing yang terdiri dari belonging, communication, customization, differentiation, personalization, security and 
convenience secara simultan mempunyai pengaruh langsung yang signifikan terhadap customer retention orientation.

2. Diduga variabel relationship marketing yang terdiri dari belonging, communication, customization, differentiation, personalization, security and convenience secara parsial mempunyai pengaruh tidak langsung yang signifikan terhadap customer retention orientation.

\section{METODE PENELITIAN}

\section{Lokasi Penelitian}

Penelitian ini dilaksanakan di bank-bank syariah di Kota Malang, yaitu; PT. BRI Syariah dan PT. BTN Syariah Kota Malang. Adapun alasan memilih lokasi penelitian di kedua bank syariah tersebut, yaitu; selain karena perkembangannya yang cukup cepat dan pesat dengan memiliki nasabah yang cukup banyak serta posisi letak yang cukup strategis, juga dikarenakan mudahnya prosedur dan persyaratan yang harus dilakukan dalam penelitian.

\section{Pendekatan Jenis Penelitian}

Pendekatan pada penelitian ini adalah pendekatan kuantitatif, sedang jenis penelitian ini adalah penelitian survei, yaitu penelitian yang mengambil sampel dari satu populasi dan menggunakan kuesioner sebagai alat pengumpulan data yang pokok (Singarimbun, 1995;5).

\section{Populasi dan Sampel Penelitian}

Populasi dalam penelitian ini adalah para nasabah, khususnya nasabah aktif dan perorangan dari PT. BRI Syariah dan PT. Bank BTN Syariah di Kota Malang. Pengambilan sampel menggunakan teknik purposive sampling, yaitu sampel dalam penelitian ditentukan dengan pertimbangan dan kriteria-kriteria tertentu yang telah ditentukan (Sudjana, 1989;45). Adapun kriteria-kriteria tersebut adalah:

Nasabah aktif bank syariah

$>$ Nasabah perorangan

Untuk penentuan sampel atau jumlah responden dalam penelitian ini ditentukan dengan menggunakan pendekatan Slovin (Sevilla, dkk, 1993;30) sebagai berikut: 


$$
\begin{aligned}
\mathrm{n} & =\frac{3100}{1+3100(0,1)^{2}} \\
& =96,87 \approx 100 \text { nasabah }
\end{aligned}
$$

Kemudian untuk menentukan jumlah sampel pada masing-masing lokasi penelitian secara proporsional (Luck and Rubin, 1987;35), sehingga jumlah sampel yang diambil adalah sebagai berikut:

1. PT. BRI Syariah Cabang Malang

$$
\mathrm{n}_{\mathrm{i}}=\frac{2000}{3100} \times 100=64,51 \text { dibulatkan menjadi } 65 \text { responden }
$$

2. PT. BTN Syariah Cabang Malang

$$
\mathrm{n}_{i}=\frac{1100}{3100} \times 100=35,48 \text { dibulatkan menjadi } 35 \text { responden }
$$

\section{Konsep dan Operasionalisasi Variabel}

Menurut Odekerken-Schroder, de Wulf and Reynolds (2000;5), dalam penelitian ini menggunakan variabel-variabel yang akan dijabarkan berikut ini:

Belonging $\left(\mathrm{X}_{1}\right)$ adalah persepsi nasabah pada sejauh mana bank memenuhi kebutuhan intrinsik nasabah sebagai bagian dari membangun hubungan. Dengan menggunakan indikator: menyediakan fasilitas fisik untuk kenyamanan nasabah, produk bank dapat memenuhi kebutuhan nasabah, menawarkan produk/jasa yang menarik.

Communication $\left(\mathrm{X}_{2}\right)$ adalah persepsi nasabah pada sejauh mana bank memulai pertukaran informasi tertulis dengan nasabah. Dengan menggunakan indikator: brosur, majalah atau koran, media elektronik (internet, mobile banking).

Customization $\left(\mathrm{X}_{3}\right)$ adalah persepsi nasabah pada sejauh mana bank menggunakan pengetahuannya tentang nasabah untuk menyesuaikan penawarannya. Dengan indikator : melakukan survey kebutuhan nasabah di masa datang, feedback (masukan / komplain).

Differentiation $\left(\mathrm{X}_{4}\right)$ adalah persepsi nasabah atas perlakuan personal pihak bank. Dengan menggunakan indikator: perhatian lebih, pelayanan khusus. 
Personalization $\left(\mathrm{X}_{5}\right)$ adalah persepsi nasabah pada sejauh mana bank menunjukkan apresiasinya pada nasabah. Dengan menggunakan indikator: mau membantu, menepati janji, bersikap ramah.

Security and convenience $\left(\mathrm{X}_{6}\right)$ adalah persepsi nasabah pada sejauh mana upaya bank untuk mengurangi resiko yang diterima nasabah dan menghemat waktu. Dengan menggunakan indikator : keamanan bertransaksi, customer service, tindakan korektif.

Customer retention orientation $(\mathrm{Y})$ adalah persepsi nasabah pada sejauh mana bank telah melakukan upaya yang dimaksudkan untuk memberikan kontribusi pada customer value. Dengan menggunakan indikator: upaya meningkatkan loyalitas nasabah, upaya memperbaiki hubungan dengan nasabah, upaya mempertahankan nasabah.

\section{Uji Instrumen}

\section{Uji Validitas}

Dalam pengujian validitas untuk tiap butir pertanyaan atau pertanyaan dalam kuesioner digunakan teknik korelasi validitas internal, yaitu mengkorelasikan skor item dengan skor total dari keseluruhan item,yang digunakan dalam penelitian ini adalah teknik Rank Spearman Correlation, yaitu untuk menentukan korelasi antara dua variabel yang diukur dengan skala pengukuran ordinal (Gasperz, 1992;124), dengan taraf signifikansi penelitian $10 \%$.

\section{Uji Reliabilitas}

Menurut Singarimbun instrument dikatakan valid atau reliabel, jika hasil perhitungan memiliki koefisien keandalan (reliabilitas) sebesar $\alpha=0,05$ atau lebih. Untuk pengujian reliabilitas dalam penelitian ini menggunakan rumus Alpha Cronbach. (Arikunto, 1998:193)

\section{Model analisis data}

Teknik analisis data yang digunakan peneliti dalam penelitian ini adalah dengan menggunakan:

\section{Regresi linier berganda.}


Pengujian hipotesis

a. Uji F (uji simultan)

b. Uji t ( uji parsial)

\section{HASIL PENELITIAN}

\section{Karakteristik Responden}

1. Karakteristik responden berdasarkan usia

Tabel 4.1.

Karakteristik responden berdasar usia

\begin{tabular}{|c|c|c|c|}
\hline No & Usia & Jumlah & Prosentase \\
\hline 1 & $16-25$ tahun & 16 & $16 \%$ \\
\hline 2 & $26-35$ tahun & 35 & $35 \%$ \\
\hline 3 & $36-45$ tahun & 14 & $14 \%$ \\
\hline 4 & $46-55$ tahun & 20 & $20 \%$ \\
\hline 5 & $>55$ tahun & 15 & $15 \%$ \\
\hline \multicolumn{2}{|r|}{ Total } & 100 & $100 \%$ \\
\hline
\end{tabular}

Sumber : Data diolah, 2007

2. Karakteristik responden berdasarkan jenis kelamin Tabel 4.2.

Karakteristik responden berdasar jenis kelamin

\begin{tabular}{|c|l|c|c|}
\hline No & Jenis kelamin & Jumlah & Prosentase \\
\hline \hline 1 & Laki-laki & 59 & $59 \%$ \\
\hline 2 & Perempuan & 41 & $41 \%$ \\
\hline \multicolumn{2}{|c|}{ Total } & 100 & $100 \%$ \\
\hline
\end{tabular}

Sumber : Data diolah, 2007

3. Karakteristik responden berdasarkan pekerjaan

Tabel 4.3.

Karakteristik responden berdasar pekerjaan

\begin{tabular}{|c|l|c|c|}
\hline No & \multicolumn{1}{|c|}{ Pekerjaan } & Jumlah & Prosentase \\
\hline \hline 1 & Pegawai Negeri / BUMN & 25 & $25 \%$ \\
\hline 2 & Pegawai Swasta & 18 & $18 \%$ \\
\hline 3 & Pengusaha / Wiraswasta & 28 & $28 \%$ \\
\hline 4 & Pelajar / Mahasiswa & 15 & $15 \%$ \\
\hline 5 & Lain-lain & 14 & $14 \%$ \\
\hline \multicolumn{2}{c|}{ Total } & 100 & $100 \%$ \\
\hline
\end{tabular}

Sumber : Data diolah, 2007 
4. Karakteristik responden berdasarkan pendidikan terakhir

Tabel 4.4.

Karakteristik responden berdasar pekerjaan

Karakteristik responden berdasar pekerjaan
\begin{tabular}{|c|l|c|c|}
\hline No & Pendidikan terakhir & Jumlah & Prosentase \\
\hline \hline 1 & SLTP & 18 & $18 \%$ \\
\hline 2 & SLTA & 28 & $28 \%$ \\
\hline 3 & Akademi / Diploma & 20 & $20 \%$ \\
\hline 4 & S1 & 22 & $22 \%$ \\
\hline 5 & S2 / S3 & 12 & $12 \%$ \\
\hline \multicolumn{2}{c|}{ Total } & 100 & $100 \%$ \\
\hline
\end{tabular}

Sumber : Data diolah, 2007

5. Karakteristik responden berdasarkan rekening bank lain

Tabel 4.5.

Karakteristik responden berdasar rekening bank lain

\begin{tabular}{|c|l|c|c|}
\hline No & Rekening bank lain & Jumlah & Prosentase \\
\hline \hline 1 & Ada & 87 & $87 \%$ \\
\hline 2 & Tidak ada & 13 & $13 \%$ \\
\hline \multicolumn{2}{r|}{ Total } & 100 & $100 \%$ \\
\hline
\end{tabular}

Sumber : Data diolah, 2007

\section{Distribusi Frekuensi Item}

Variabel Bebas $(\mathrm{X})$

1. Variabel belonging $\left(\mathrm{X}_{1}\right)$

Tabel 4.6.

Distribusi Frekuensi Item Variabel Belonging (X1)

\begin{tabular}{|c|c|c|c|c|c|c|c|c|c|c|c|c|c|}
\hline \multirow{3}{*}{ Item } & \multirow{2}{*}{\multicolumn{2}{|c|}{$\frac{1}{\text { TB }}$}} & \multirow{2}{*}{\multicolumn{2}{|c|}{$\frac{2}{K B}$}} & \multirow{2}{*}{\multicolumn{2}{|c|}{$\frac{3}{C}$}} & \multirow{2}{*}{\multicolumn{2}{|c|}{$\frac{4}{B}$}} & \multirow{2}{*}{\multicolumn{2}{|c|}{$\begin{array}{c}5 \\
\text { SB }\end{array}$}} & \multirow{2}{*}{\multicolumn{2}{|c|}{ Total }} & \multirow{3}{*}{$\begin{array}{c}\text { Statistik } \\
\text { Mean }\end{array}$} \\
\hline & & & & & & & & & & & & & \\
\hline & f & $\%$ & f & $\%$ & f & $\%$ & f & $\%$ & f & $\%$ & f & $\%$ & \\
\hline $\mathrm{X} 1.1$ & - & - & 5 & 5 & 7 & 7 & 66 & 66 & 22 & 22 & 100 & 100 & 4,05 \\
\hline $\mathrm{X} 1.2$ & - & - & 3 & 3 & 13 & 13 & 67 & 67 & 17 & 17 & 100 & 100 & 3,98 \\
\hline $\mathrm{X} 1.3$ & - & - & 4 & 4 & 15 & 15 & 61 & 61 & 20 & 20 & 100 & 100 & 3,97 \\
\hline
\end{tabular}

Sumber : Data diolah, 2007

2. Variabel communication $\left(\mathrm{X}_{2}\right)$

Tabel 4.7.

Distribusi Frekuensi Item Variabel communication $\left(\mathrm{X}_{2}\right)$

\begin{tabular}{|c|c|c|c|c|c|c|c|c|c|c|c|c|c|}
\hline \multirow{3}{*}{ Item } & & & \multirow{2}{*}{\multicolumn{2}{|c|}{$\begin{array}{c}2 \\
K B\end{array}$}} & \multirow{2}{*}{\multicolumn{2}{|c|}{$\begin{array}{l}3 \\
C\end{array}$}} & \multirow{2}{*}{\multicolumn{2}{|c|}{4}} & \multirow{2}{*}{\multicolumn{2}{|c|}{$\begin{array}{c}5 \\
\text { SB }\end{array}$}} & \multirow{2}{*}{\multicolumn{2}{|c|}{ Total }} & \multirow{2}{*}{ Statistik } \\
\hline & \multicolumn{2}{|c|}{ TB } & & & & & & & & & & & \\
\hline & f & $\%$ & $\mathbf{f}$ & $\%$ & $\mathbf{f}$ & $\%$ & & $\%$ & $f$ & $\%$ & f & $\%$ & Mean \\
\hline
\end{tabular}




\begin{tabular}{|c|c|c|c|c|c|c|c|c|c|c|c|c|c|}
$\mathrm{X} 2.1$ & - & - & 4 & 4 & 18 & 18 & 68 & 68 & 10 & 10 & 100 & 100 & 3,84 \\
\hline $\mathrm{X} 2.2$ & 1 & 1 & 2 & 2 & 11 & 11 & 75 & 75 & 11 & 11 & 100 & 100 & 3,93 \\
\hline $\mathrm{X} 2.3$ & 1 & 1 & 5 & 5 & 17 & 17 & 50 & 50 & 27 & 27 & 100 & 100 & 3,97 \\
\hline
\end{tabular}

Sumber : Data diolah, 2007

3. Variabel customization $\left(\mathrm{X}_{3}\right)$

Tabel 4.8.

Distribusi Frekuensi Item Variabel customization $\left(X_{3}\right)$

\begin{tabular}{|c|c|c|c|c|c|c|c|c|c|c|c|c|c|}
\hline \multirow{3}{*}{ Item } & \multirow{2}{*}{\multicolumn{2}{|c|}{$\frac{1}{\text { TB }}$}} & \multirow{2}{*}{\multicolumn{2}{|c|}{$\frac{2}{\mathrm{~KB}}$}} & \multirow{2}{*}{\multicolumn{2}{|c|}{$C$}} & \multirow{2}{*}{\multicolumn{2}{|c|}{$\frac{4}{B}$}} & \multirow{2}{*}{\multicolumn{2}{|c|}{$\frac{5}{\text { SB }}$}} & \multirow{2}{*}{\multicolumn{2}{|c|}{ Total }} & \multirow{3}{*}{$\begin{array}{c}\text { Statistik } \\
\text { Mean }\end{array}$} \\
\hline & & & & & & & & & & & & & \\
\hline & $\mathbf{f}$ & $\%$ & f & $\%$ & $\mathbf{f}$ & $\%$ & $\mathbf{f}$ & $\%$ & f & $\%$ & $\mathbf{f}$ & $\%$ & \\
\hline X3.1 & - & - & 3 & 3 & 18 & 18 & 62 & 62 & 17 & 17 & 100 & 100 & 3,93 \\
\hline X3.2 & 2 & 2 & 2 & 2 & 5 & 5 & 74 & 74 & 17 & 17 & 100 & 100 & 4,02 \\
\hline
\end{tabular}

Sumber : Data diolah, 2007

4. Variabel differentiation $\left(\mathrm{X}_{4}\right)$

Tabel 4.9.

Distribusi Frekuensi Item Variabel differentiation $\left(X_{4}\right)$

\begin{tabular}{|c|c|c|c|c|c|c|c|c|c|c|c|c|c|}
\hline \multirow{3}{*}{ Item } & \multirow{2}{*}{\multicolumn{2}{|c|}{$\begin{array}{c}1 \\
\text { TB }\end{array}$}} & \multirow{2}{*}{\multicolumn{2}{|c|}{$\begin{array}{c}2 \\
K B\end{array}$}} & \multirow{2}{*}{\multicolumn{2}{|c|}{$\frac{3}{C}$}} & \multirow{2}{*}{\multicolumn{2}{|c|}{$\frac{4}{B}$}} & \multirow{2}{*}{\multicolumn{2}{|c|}{$\begin{array}{c}5 \\
\text { SB }\end{array}$}} & \multirow{2}{*}{\multicolumn{2}{|c|}{ Total }} & \multirow{3}{*}{$\begin{array}{c}\text { Statistik } \\
\text { Mean }\end{array}$} \\
\hline & & & & & & & & & & & & & \\
\hline & $\mathbf{f}$ & $\%$ & 1 & $\%$ & $\mathbf{f}$ & $\%$ & $\mathbf{f}$ & $\%$ & $\mathbf{f}$ & $\%$ & f & $\%$ & \\
\hline X4.1 & - & - & 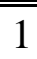 & 1 & 11 & 11 & 50 & 50 & 38 & 38 & 100 & 100 & 4,25 \\
\hline X4.2 & - & - & 3 & 3 & 8 & 8 & 67 & 67 & 22 & 22 & 100 & 100 & 4,08 \\
\hline
\end{tabular}

Sumber : Data diolah, 2007

5. Variabel personalization $\left(\mathrm{X}_{5}\right)$

Tabel 4.10.

Distribusi Frekuensi Item Variabel personalization $\left(X_{5}\right)$

\begin{tabular}{|c|c|c|c|c|c|c|c|c|c|c|c|c|c|}
\hline \multirow{3}{*}{ Item } & \multirow{2}{*}{\multicolumn{2}{|c|}{$\frac{1}{\text { TB }}$}} & \multirow{2}{*}{\multicolumn{2}{|c|}{$\frac{2}{\mathrm{~KB}}$}} & \multirow{2}{*}{\multicolumn{2}{|c|}{4}} & \multirow{2}{*}{\multicolumn{2}{|c|}{$\frac{4}{B}$}} & \multirow{2}{*}{\multicolumn{2}{|c|}{$\frac{5}{S B}$}} & \multirow{2}{*}{\multicolumn{2}{|c|}{ Total }} & \multirow{3}{*}{$\begin{array}{c}\text { Statistik } \\
\text { Mean }\end{array}$} \\
\hline & & & & & & & & & & & & & \\
\hline & $\mathbf{f}$ & $\%$ & c & $\%$ & $\mathbf{f}$ & $\%$ & f & $\%$ & f & $\%$ & $\mathbf{f}$ & $\%$ & \\
\hline X5.1 & - & 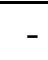 & & 4 & 28 & 28 & 51 & 51 & 17 & 17 & 100 & 100 & 3,81 \\
\hline $\mathrm{X} 5.2$ & 2 & 2 & 1 & 1 & 28 & 28 & 49 & 49 & 20 & 20 & 100 & 100 & 3,84 \\
\hline $\mathrm{X} 5.3$ & - & - & 6 & 6 & 14 & 14 & 57 & 57 & 23 & 23 & 100 & 100 & 3,97 \\
\hline
\end{tabular}

Sumber : Data diolah, 2007

6. Variabel security and convenience $\left(\mathrm{X}_{6}\right)$

Tabel 4.11.

Distribusi Frekuensi Item Variabel security and convenience $\left(\mathrm{X}_{6}\right)$

\begin{tabular}{|c|c|c|c|c|c|c|c|c|c|c|c|c|c|}
\hline \multirow{3}{*}{ Item } & \multirow{2}{*}{\multicolumn{2}{|c|}{$\frac{1}{\text { TB }}$}} & \multirow{2}{*}{\multicolumn{2}{|c|}{$\frac{2}{\mathrm{~KB}}$}} & \multirow{2}{*}{\multicolumn{2}{|c|}{3}} & \multirow{2}{*}{\multicolumn{2}{|c|}{4}} & \multirow{2}{*}{\multicolumn{2}{|c|}{ SB }} & \multirow{2}{*}{\multicolumn{2}{|c|}{ Total }} & \multirow{2}{*}{ Statistik } \\
\hline & & & & & & & & & & & & & \\
\hline & f & $\%$ & f & $\%$ & f & $\%$ & f & $\%$ & f & $\%$ & f & $\%$ & Mean \\
\hline
\end{tabular}




\begin{tabular}{|l|l|l|l|l|l|l|l|l|l|l|l|l|l|} 
X6.1 & - & - & 5 & 5 & 25 & 25 & 42 & 42 & 28 & 28 & 100 & 100 & 3,93 \\
\hline X6.2 & - & - & 6 & 6 & 12 & 12 & 70 & 70 & 12 & 12 & 100 & 100 & 3,88 \\
\hline X6.3 & 5 & 5 & 2 & 2 & 18 & 18 & 60 & 60 & 15 & 15 & 100 & 100 & 3,78 \\
\hline
\end{tabular}

Sumber : Data diolah, 2007

\section{Variabel Terikat (Y)}

Variabel customer retention orientation $(\mathrm{Y})$

Tabel 4.12.

Distribusi Frekuensi Item Variabel customer retention orientation (Y)

\begin{tabular}{|c|c|c|c|c|c|c|c|c|c|c|c|c|c|}
\hline \multirow{3}{*}{ Item } & \multirow{2}{*}{\multicolumn{2}{|c|}{$\frac{1}{\text { TB }}$}} & \multirow{2}{*}{\multicolumn{2}{|c|}{$\frac{2}{K B}$}} & \multirow{2}{*}{\multicolumn{2}{|c|}{$\begin{array}{l}3 \\
C\end{array}$}} & \multirow{2}{*}{\multicolumn{2}{|c|}{$\begin{array}{l}4 \\
\text { B }\end{array}$}} & \multirow{2}{*}{\multicolumn{2}{|c|}{$\begin{array}{c}5 \\
\text { SB }\end{array}$}} & \multirow{2}{*}{\multicolumn{2}{|c|}{ Total }} & \multirow{3}{*}{$\begin{array}{c}\text { Statistik } \\
\text { Mean }\end{array}$} \\
\hline & & & & & & & & & & & & & \\
\hline & $\mathbf{f}$ & $\%$ & f & $\%$ & f & $\%$ & f & $\%$ & f & $\%$ & f & $\%$ & \\
\hline Y1 & - & - & 5 & 5 & 17 & 17 & 55 & 55 & 23 & 23 & 100 & 100 & 286 \\
\hline $\mathrm{Y} 2$ & 1 & 1 & 2 & 2 & 4 & 4 & 57 & 57 & 36 & 36 & 100 & 100 & 4,25 \\
\hline Y3 & 1 & 1 & 2 & 2 & 25 & 25 & 45 & 45 & 27 & 27 & 100 & 100 & 3,95 \\
\hline
\end{tabular}

Sumber : Data diolah, 2007

\section{Uji Validitas}

Tabel 4.13.

Hasil Uji Validitas untuk semua variabel

\begin{tabular}{|c|c|c|c|c|c|}
\hline No & Variabel & Item & $\mathbf{r}$ & Probabilitas & Keterangan \\
\hline \multirow[t]{3}{*}{1} & \multirow[t]{3}{*}{ Belonging $\left(\mathrm{X}_{1}\right)$} & $\mathrm{X} 1.1$ & 0,770 & 0,000 & Valid \\
\hline & & $\mathrm{X} 1.2$ & 0,810 & 0,000 & Valid \\
\hline & & $\mathrm{X} 1.3$ & 0,753 & 0,000 & Valid \\
\hline \multirow[t]{3}{*}{2} & \multirow[t]{3}{*}{ Communication $\left(\mathrm{X}_{2}\right)$} & $\mathrm{X} 2.1$ & 0,776 & 0,000 & Valid \\
\hline & & $\mathrm{X} 2.2$ & 0,836 & 0,000 & Valid \\
\hline & & $\times 2.3$ & 0,819 & 0,000 & Valid \\
\hline \multirow[t]{2}{*}{3} & \multirow[t]{2}{*}{ Customization $\left(\mathrm{X}_{3}\right)$} & X3.1 & 0,855 & 0,000 & Valid \\
\hline & & X3.2 & 0,859 & 0,000 & Valid \\
\hline \multirow[t]{2}{*}{4} & \multirow[t]{2}{*}{ Differentiation $\left(\mathrm{X}_{4}\right)$} & $\mathrm{X} 4.1$ & 0,857 & 0,000 & Valid \\
\hline & & $\mathrm{X} 4.2$ & 0,786 & 0,000 & Valid \\
\hline \multirow[t]{3}{*}{5} & \multirow[t]{3}{*}{ Personalization $\left(\mathrm{X}_{5}\right)$} & $\mathrm{X} 5.1$ & 0,855 & 0,000 & Valid \\
\hline & & X5.2 & 0,795 & 0,000 & Valid \\
\hline & & X5.3 & 0,843 & 0,000 & Valid \\
\hline \multirow[t]{3}{*}{7} & \multirow[t]{3}{*}{ Security and convenience $\left(\mathrm{X}_{6}\right)$} & X6.1 & 0,837 & 0,000 & Valid \\
\hline & & $\mathrm{X} 6.2$ & 0,832 & 0,000 & Valid \\
\hline & & X6.3 & 0,886 & 0,000 & Valid \\
\hline \multirow[t]{2}{*}{8} & \multirow[t]{2}{*}{ Customer retention orientation $(\mathrm{Y})$} & $\mathrm{Y} 1$ & 0,728 & 0,000 & Valid \\
\hline & & $\mathrm{Y} 2$ & 0,840 & 0,000 & Valid \\
\hline
\end{tabular}




\begin{tabular}{|l|c|c|c|c|}
\cline { 2 - 5 } & Y3 & 0,734 & 0,000 & Valid \\
\hline
\end{tabular}

Sumber : Data diolah, 2007

\section{Uji Reliabilitas}

Tabel 4.14.

Hasil Uji Reliabilitas untuk semua variabel

\begin{tabular}{|c|l|c|c|}
\hline No & \multicolumn{1}{|c|}{ Variabel } & Alpha & Keterangan \\
\hline \hline 1 & Belonging $\left(\mathrm{X}_{1}\right)$ & 0,670 & Reliabel \\
\hline 2 & Communication $\left(\mathrm{X}_{2}\right)$ & 0,723 & Reliabel \\
\hline 3 & Customization $\left(\mathrm{X}_{3}\right)$ & 0,638 & Reliabel \\
\hline 4 & Differentiation $\left(\mathrm{X}_{4}\right)$ & 0,666 & Reliabel \\
\hline 5 & Personalization $\left(\mathrm{X}_{5}\right)$ & 0,774 & Reliabel \\
\hline 7 & Security and convenience $\left(\mathrm{X}_{7}\right)$ & 0,805 & Reliabel \\
\hline 8 & Customer retention orientation $(\mathrm{Y})$ & 0,642 & Reliabel \\
\hline
\end{tabular}

Sumber : Data diolah, 2007

\section{Analisis Regresi Linier Berganda}

Tabel 4.15.

Rekapitulasi Analisis Regresi Linier Berganda

\begin{tabular}{|c|c|c|c|c|c|c|c|}
\hline Variabel & B (koefisien regresi) & Beta & $\mathbf{t}_{\text {hitung }}$ & $\mathbf{t}_{\text {tabel }}$ & $\operatorname{Sig} \mathbf{t}$ & Alpha & Hipotesis \\
\hline Konstanta & 0,580 & - & 0,519 & - & 0,605 & - & - \\
\hline $\mathrm{X}_{1}$ & 0,320 & 0,289 & 3,130 & 1,980 & 0,002 & 0,05 & diterima \\
\hline $\mathrm{X}_{2}$ & 0,285 & 0,277 & 2,769 & 1,980 & 0,007 & 0,05 & ditolak \\
\hline$X_{3}$ & 0,371 & 0,247 & 2,749 & 1,980 & 0,007 & 0,05 & ditolak \\
\hline$X_{4}$ & 0,069 & 0,049 & 0,618 & 1,980 & 0,538 & 0,05 & ditolak \\
\hline $\mathrm{X}_{5}$ & 0,049 & $-0,054$ & $-0,552$ & 1,980 & 0,582 & 0,05 & ditolak \\
\hline $\mathrm{X}_{6}$ & 0,123 & 0,145 & 1,416 & 1,980 & 0,160 & 0,05 & ditolak \\
\hline \multicolumn{4}{|l|}{$\mathrm{N}=100$} & \multicolumn{4}{|c|}{ F hitung $=21,294$} \\
\hline \multicolumn{4}{|l|}{$\mathrm{R}=0,761$} & \multicolumn{4}{|c|}{ F Tabel $=2,19$} \\
\hline \multicolumn{4}{|c|}{ R Square $=0,579$} & \multicolumn{4}{|c|}{ Sig F=0,000 } \\
\hline \multicolumn{4}{|c|}{ Adjusted R Square $=0,552$} & \multicolumn{4}{|c|}{ Alpha $=0,05$} \\
\hline
\end{tabular}

Sumber : Data diolah, 2007 
PEMBAHASAN HASIL PENELITIAN DALAM PERSPEKTIF ISLAM

Dari penelitian yang telah dilakukan, menunjukkan bahwa relationship marketing yang yang terdiri dari belonging (X1), communication (X2), customization(X3), differentiation (X4), personalization (X5) dan security and convenience $(\mathrm{X} 6)$ secara simultan mempunyai hubungan dan pengaruh terhadap variabel terikat customer retention orientation ( $\mathrm{Y}$ ) nasabah bank syariah di Kota Malang.

Berdasarkan penelitian ini, bank syariah sebagai lembaga yang memberikan relationship marketing terhadap nasabahnya harus memperhatikan kekurangan yang selama ini masih dirasakan nasabah. Ini dilakukan guna meningkatkan customer retention orientation pada bank syariah.

Dalam melakukan relationship marketing tidak lepas dengan pelayanan yang merupakan salah satu kegiatan dalam bidang bisnis. Sehingga sebagaimana salah satu sifat dari Rasulullah dalam berbisnis harus bersikap jujur, yang berarti selalu melandaskan ucapan, keyakinan, serta perbuatan berdasarkan ajaran Islam. Oleh karena itu Allah memerintahkan orang-orang yang beriman untuk senantiasa memiliki sifat shiddiq dan juga dianjurkan untuk menciptakan lingkungan shiddiq.

Dalam dunia bisnis kejujuran bisa juga ditampilkan dalam bentuk kesungguhan dan ketepatan, baik ketepatan waktu, janji, pelayanan, pelaporan, mengakui kelemahan dan kekurangan (tidak ditutup-tutupi) yang kemudian diperbaiki secara terus-menerus, serta menjauhkan diri dari berbuat bohong dan menipu (baik kepada diri sendiri, teman, perusahaan maupun mitra kerja). Termasuk memberikan informasi yang penuh kebohongan adalah iklan-iklan di media tulis dan elektronik. Bisnis yang dipenuhi dengan kebohongan dan manipulasi tidak akan mendapat rahmat dan barokah dari Allah SWT. (Hermawan dan Muhammad Syakir Sula, 2006:124).

Selain berbuat jujur maka dilandasi dengan pekerjaan yang berkualitas, karena suatu pekerjaan yang berkualitas adalah pekerjaan yang dicintai Allah SWT. Menurut Tasmara $(2002,100)$ bahwa pribadi muslim yang seharusnya dan berakhlak mulia itu akan menjadikan setiap tindakan adalah pelayanan yang 
berkualitas sehingga orang yang ada disekitarnya merasakan kedamaiannya, seperti dalam hadist Nabi Muhammad SAW sebagai berikut:
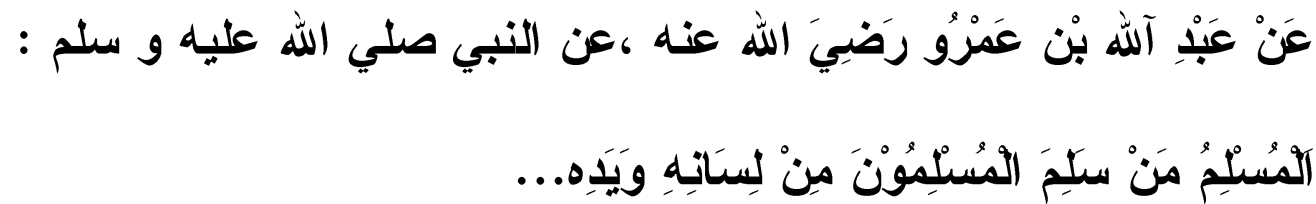

"Diriwayatkan dari Abdullah bin Amr ra. Bahwa Rasulullah pernah bersabda, "seseorang muslim adalah orang yang tidak merugikan muslim lainnya dengan lidah maupun kedua tangannya"

Dari ungkapan hadist diatas maka kinerja seseorang yang memberikan pelayan memiliki etika yang baik tidak menyakiti maupun berbuat curang kepada orang lain.

Selanjutnya adalah memberikan kemudahan kepada yang kesulitan. Membantu nasabah yang mengalami kesulitan dalam melakukan proses transaksi di bank syariah sehingga memberikan kemudahan bagi semua pihak. Sebagaimana dalam hadist Nabi Muhammad SAW sebagai berikut:

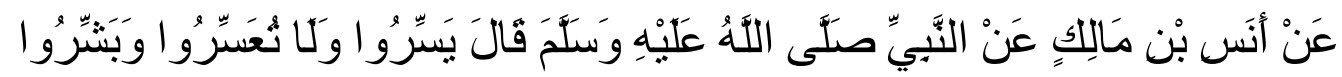
وَّا ثُنَفِّر

"Diriwayatkan dari Annas Bin Malik bahwasanya Nabi SAW bersabda, "Permudahkanlah jangan kalian mempersulit dan kabarkanlah berita gembira dan janganlah kalian menakut-nakuti."

Dalam menciptakan keinginan dan harapan dari para nasabah maka relationship marketing perlu ditingkatkan menjadi lebih baik. Dalam Islam hanya memerintahkan atau menganjurkan pekerjaan yang baik dan bermanfaat bagi kemanusiaan, agar setiap pekerjaan mampu memberikan nilai tambah dan dapat mengangkat derajat manusia baik secara individu maupun kelompok.

Dari ayat diatas merupakan suatu pesan iman yang membawa manusia kepada orientasi nilai dan kualitas. Pekerjaan yang standar adalah pekerjaan yang bermanfaat bagi individu dan masyarakat, secara material dan moralspiritual. Tolok ukurnya adalah pesan syariah yang semata-mata merupakan rahmat bagi manusia. 


\section{IMPLIKASI PENELITIAN}

Berdasarkan dari hasil penelitian dan pembahasan yang telah diuraikan diatas, maka dapat disimpulkan bahwa keenam variabel relationship marketing yang terdiri dari belonging (X1), communication $(\mathrm{X} 2)$, customization(X3), differentiation (X4), personalization (X5) dan security and convenience (X6) yang diberikan oleh bank syariah di Kota Malang akan mempunyai implikasi tersendiri bagi lembaga antara lain:

1. Belonging (X1), Berdasarkan tabel 4.6 item fasilitas fisik memberikan layanan yang sudah memenuhi nasabah $\left(X_{1.1}\right)$ merupakan item yang memiliki distribusi rata-rata tertinggi yaitu 4,05. Sedangkan item penawaran produk bank syariah $\left(\mathrm{X}_{1.3}\right)$ merupakan item yang memiliki distribusi rata-rata terendah yaitu 3,97. Hal ini berarti produk bank belum menarik bagi nasabah bank syariah di Kota Malang.

2. Communication (X2), Berdasarkan tabel 4.7 item komunikasi melalui media elektronik memberikan informasi yang sudah diharapkan nasabah ( $\left.\mathrm{X}_{2.3}\right)$ merupakan item yang memiliki distribusi rata-rata tertinggi yaitu 3,97. Sedangkan item komunikasi melalui brosur $\left(X_{1.3}\right)$ merupakan item yang memiliki distribusi rata-rata terendah yaitu 3,84. Hal ini berarti komunikasi melalui brosur belum dirasakan benar-benar bagi nasabah bank syariah di Kota Malang.

3. Customization(X3), Berdasarkan tabel 4.8 item mau menerima masukan/komplain sudah sesuai dengan diharapkan nasabah ( $\left.\mathrm{X}_{3-2}\right)$ merupakan item yang memiliki distribusi rata-rata tertinggi yaitu 4,02. Sedangkan item melakukan survey kebutuhan nasabah yang akan datang $\left(\mathrm{X}_{3-1}\right)$ merupakan item yang memiliki distribusi rata-rata terendah yaitu 3,93. Hal ini berarti bank syariah di Kota Malang belum benar-benar melakukan survey kebutuhan nasabah dimasa yang akan datang.

4. Differentiation (X4), Berdasarkan tabel 4.9 item mau memberikan perhatian lebih sesuai dengan diharapkan nasabah $\left(\mathrm{X}_{4-1}\right)$ merupakan item yang memiliki distribusi rata-rata tertinggi yaitu 4,25. Sedangkan item memberikan pelayanan khusus $\left(X_{4-2}\right)$ merupakan item yang memiliki distribusi rata-rata terendah yaitu 
4,05. Hal ini berarti bank syariah di Kota Malang belum benar-benar memberikan pelayanan yang khusus kepada nasabahnya.

5. Personalization (X5), Berdasarkan tabel 4.10 item memberikan pelayanan yang ramah sudah baik $\left(X_{5-3}\right)$ merupakan item yang memiliki distribusi rata-rata tertinggi yaitu 3,97. Sedangkan item memberikan mau membantu kalau nasabah menemukan kesulitan dinilai belum begitu dirasakan oleh nasabah $\left(X_{5-1}\right)$ merupakan item yang memiliki distribusi rata-rata terendah yaitu 3,84. Hal ini berarti bank syariah di Kota Malang belum benar-benar memberikan bantuan sesuai dengan harapan dari nasabahnya.

6. Security and convenience (X6), Berdasarkan tabel 4.11 item memberikan rasa aman pada saat nasabah melakukan transaksi sudah baik $\left(X_{6-1}\right)$ merupakan item yang memiliki distribusi rata-rata tertinggi yaitu 3,93. Sedangkan item mau menyadari kalau ada kesalahan dinilai belum begitu dirasakan oleh nasabah $\left(\mathrm{X}_{6-3}\right)$ merupakan item yang memiliki distribusi rata-rata terendah yaitu 3,78. Hal ini berarti bank syariah di Kota Malang belum mau melakukan tindakan korektif terhadap kesalahan yang dilakukan.

\section{Kesimpulan}

Berdasarkan hasil penelitian yang dilakukan maka dapat disimpulkan sebagai berikut:

1. Berdasarkan tabel 4.15 , dapat diketahui bahwa uji hipotesis secara simultan yang menguji pengaruh secara bersama-sama variabel bebas terhadap variabel terikat digunakan uji F. Didapatkan F hitung $(21,294)>$ dari F tabel $(2,19)$ sedangkan signifikansi $(0,000)<$ dari alpha pada taraf $5 \%$ atau 0,05 . Sehingga Ha yang berbunyi ada pengaruh yang signifikan antara variabel relationship marketing yang terdiri dari belonging, communication, customization, differentiation, personalization, security and convenience terhadap customer retention orientation secara simultan dapat diterima.

2. Untuk menguji hipotesis secara parsial digunakan uji t yaitu untuk menguji secara parsial variabel bebas terhadap variabel terikat. Pada tabel 4.15 dapat dilihat hasil perhitungan $t$ hitung pada setiap variabel $\mathrm{X} 1, \mathrm{X} 2, \mathrm{X} 3, \mathrm{X} 4, \mathrm{X} 5$ dan X6 dengan nilai $p \geq 0,05$, apakah berpengaruh secara signifikan terhadap 
perubahan nilai $\mathrm{Y}$ (variabel terikat) dengan cara membandingkan $\mathrm{t}$ tabel dengan $\mathrm{N}=$ jumlah sampel 100 dengan $\alpha=0,05$ didapat $\mathrm{t}$ tabel sebesar 1,980, maka diperoleh:

4. thitung $\mathrm{X} 13,130>\mathrm{t}$ tabel 1,980 dan nilai $p=0,002<0,05$, sehingga Ha yang berbunyi ada pengaruh yang signifikan antara belonging dengan customer retention orientation diterima.

5. thitung X2 2,769 $>$ t tabel 1,980 dan nilai $p=0,007<0,05$, sehingga Ha yang berbunyi ada pengaruh yang signifikan antara communication dengan customer retention orientation diterima.

6. thitung X3 2,749 > t tabel 1,980 dan nilai $p=0,007<0,05$, sehingga Ha yang berbunyi ada pengaruh yang signifikan antara customization dengan customer retention orientation diterima.

7. thitung X4 0,618< t tabel 1,980 dan nilai $p=0,538>0,05$, sehingga Ha yang berbunyi ada pengaruh yang signifikan antara differentiation dengan customer retention orientation ditolak.

8. $\mathrm{t}$ hitung $\mathrm{X} 5-0,552<\mathrm{t}$ tabel 1,980 dan nilai $p=0,582>0,05$, sehingga Ha yang berbunyi ada pengaruh yang signifikan antara personalization dengan customer retention orientation ditolak.

9. $\mathrm{t}$ hitung X6 1,146 < t tabel 1,980 dan nilai $p=0,160<0,05$, sehingga Ha yang berbunyi ada pengaruh yang signifikan antara security and convenience dengan customer retention orientation ditolak.

\section{Saran}

Berdasarkan hasil penelitian maka peneliti perlu memberikan saran,yaitu:

1. Bagi peneliti selanjutnya, dijadikan sebagai rujukan dalam melakukan penelitian selanjutnya terlebih mengenai relationship marketing dengan lebih sempurna lagi.

2. Bagi pihak perbankan syariah di Kota Malang

a. Sehubungan dengan relationship marketing yang telah diberikan kepada nasabah selama ini, maka penelitian dapat dijadikan acuan dalam pengambilan keputusan dan sebagai bahan evaluasi lembaga untuk menjadikan lembaga perbankan syariah menjadi lebih baik. 
b. Relationship marketing yang selama ini diberikan kepada nasabah agar selalu ditingkatkan untuk menjadikan nasabah mau bertahan menjadi nasabah di perbankan syariah tersebut.

c. Item relationship marketing yang dinilai oleh nasabah kurang ataupun tidak sesuai dengan kenyataan seperti; menawarkan produk/jasa yang menarik, berkomunikasi dengan nasabah melalui penyebaran brosur, melakukan survei terhadap kebutuhan nasabah dimasa yang akan datang, memberikan pelayanan yang lebih khusus dan mau membantu nasabah yang kesulitan dalam melakukan transaksi keuangan di bank syariah serta mau melakukan tindakan korektif apabila ada kesalahan yang dilakukan oleh karyawan bank syariah harus diperbaiki dan dibenahi agar nasabah mau bertahan di bank syariah tersebut.

\section{DAFTAR PUSTAKA}

Arikunto, Suharsimi, 2006. Prosedur Penelitian Suatu Pendekatan Praktik. Edisi ketigabelas. Penerbit RINEKA CIPTA, Jakarta.

Chan, Shiu-Fai. 2002. Relationship Building And Interactivity : An Exploratory Study On Corporate-Customer Relationship Building Via Different Interaction Channels In Retail Banking. University of Hong Kong.

Chan, Syafruddin. 2003. Relationship Marketing : Inovasi Pemasaran Yang Membuat Pelanggan Bertekuk Lutut. PT Gramedia Pustaka Utama. Jakarta.

De Wulf, K. G. Odekerken-Schroder and P. Schumacher. 2000. Why It Takes Two To Build Successful Buyer-Seller Relationship. www.feb.ugent.be/fac/research/WP/Papers/wp_00_89.pdf. June, 6, 2004.

Hadist Bukhari : 67 (dalam CD Hadist al-Hadist Syarief)

Hafidhuddin, Didin. Hendri Tanjung, 2003. Manajemen Syariah Dalam Praktik. Penerbit Gema Insani Press, Jakarta.

Hermawan Kertajaya. Muhammad Syakir Sula, 2006. Syariah Marketing, Bandung. Mizan Pustaka. 
Indriantoro, Nur, 1999. Metodologi Penelitian Bisnis Untuk Akuntansi E Manajemen.

Edisi pertama, Penerbit BPFE, Yogyakarta.

Kandampully, J. and R. Duddy, 1999. Relationship Marketing : A Concept Beyond The Primary Relationship. Marketing Intelligence \& Planning 17/7. MCB University Press.

Kasmir, 2001. Bank dan Lembaga Keuangan Lainnya. Edisi Revisi 2001. Penerbit PT. RajaGrafindo Persada, Jakarta.

Kotler, Philip, dkk, 2000. Manajemen Pemasaran Perspektif Asia. Penerbit ANDI dan Pearson Education Asia Pte.Ltd, Yogyakarta. , 2000. Manajemen Pemasaran. edisi Bahasa Indonesia. alih bahasa:

Hendra Teguh, Ronny A. Rusli dan Benyamin Molan, PT Prenhallindo. Jakarta.

Liljander, Veronica and Tore Strandvik, 1995. The Nature Of Customer Relationship In Service. Advances In Services Marketing And Management. Volume 4. JAI Press inc.. London.

Lindgreen, A. and I. Crawford, 1999. Implementing, Monitoring and Measuring A Programme of Relationship Marketing. Marketing Intelligence $\mathcal{E}$ Planning 17/5. MCB University Press.

Luck, D.J., and R.S. Rubin, 1987. Marketing Research. seventh edition. PrenticeHall Inc. New Jersey.

Mustikowati, Rita Indah, 2004, Analisis Faktor-Faktor Kualitas Layanan Yang Mempengaruhi Keputusan Pembelian Pada Department Store Di Kota Malang. Tesis. Pascasarjana Universitas Brawijaya

Nazir, Moh, 2003. Metode Penelitian. Cetakan kelima, Penerbit Ghalia Indonesia, Jakarta.

Odekerken-Schroeder, G.O., K. de Wulf, and K.E. Reynolds, 2000. Relationship Marketing Effectiveness in Retailing : A Contingency Approach. MAXX Working Paper 2000-02.

Payne, Adrian, 1993. The Essence of Services Marketing. Prentice Hall International (UK) Ltd., New York. 
Raciti, Maria, 2002. Relationship Marketing In A Higher Education Context : An Exploratory Study Of Student's Perceptions. ANZMAC 2002 Conference Proceedings.

Rangkuti, Freddy, 2001. Riset Pemasaran. Penerbit PT. Gramedia Pustaka Tama, Jakarta , 2006. Measuring Customer Satisfaction. Penerbit PT. Gramedia Pustaka Tama, Jakarta

Santoso, Singgih, 2002. Buku latihan SPSS statistic parametik. Penerbit PT. Elex Media Komputindo, Jakarta.

Sevilla, Consuelo G. dkk., 1993. Pengantar Metode Penelitian. Penerbit UI Press, Jakarta.

Singarimbun, Masri, 1995. Metode Penelitian Survai. Cetakan kedua, Penerbit LP3ES Jakarta.

Sugiyono, 2005. Statistik Untuk Penelitian. Penerbit Alfabeta, Bandung.

Sugiyono, 2005. Metode Penelitian Bisnis. Cetakan kedelapan, Penerbit CV. Alfabeta, Bandung.

Supranto, Jaya, 1997. Pengukuran Tingkat Kepuasan Pelanggan Untuk Menaikkan Pangsa Pasar. Penerbit Rineka Cipta, Jakarta.

Swasta, Basu dan Handoko Hani, 2000. Manajemen Pemasaran: Analisa Perilaku Konsumen. Penerbit BPFE, Yogyakarta.

Tandjung, Jenu Widjaja, 2004. Marketing Manajemen.

Tasmara, 2002. Membudayakan Etos Kerja Islam. Penerbit Gema Insani Press, Jakarta.

Tjiptono, Fandy, 1997. Strategi Pemasaran. Edisi II, Penerbit ANDI, Yogyakarta. , 2002. Manajemen Jasa. Penerbit ANDI, Yogyakarta. , 2005. Service Quality and Satisfaction. Penerbit ANDI, Yogyakarta.

Trimaryuni, Dwi, 2002. Analisis faktor- faktor yang mempengaruhi kepuasan pelanggan dan perilaku setelah menabung pada Bank Pemerintah di Kota Malang. Tesis. Pascasarjana Universitas Brawijaya.

Umar Husein, 1999. Metodologi Penelitian Aplikasi dalam Pemasaran. Gramedia Pustaka Utama, Jakarta. 
Yazid, 1999. Pemasaran Jasa: Konsep dan Implementasi: Ekonesia. Fakultas

*) Irmayanti Hasan, MM, Dosen Fakultas Ekonomi UIN Malang 